\title{
UDC 351
}

DOI: $10.31110 / 2789-6536 / 2021-2 / 001$

\section{PROBLEMS OF HARMONIZATION OF UKRAINIAN LEGISLATION WITH EUROPEAN REQUIREMENTS ON GEOGRAPHICAL INDICATIONS OF DOMESTIC GOODS}

\author{
Nataliia Cherevychna \\ $\mathrm{PhD}$, Associate Professor, Department of Public Administration and \\ Entrepreneurship, National Aerospace University Zhukovsky M.E. «Kharkov \\ Aviation Institute» \\ ORCID : 0000-0002-6660-5366 \\ Nataliia Hrin \\ Lecturer, Kropyvnytskyi Applied College of Food and Trade \\ ORCID : 0000-0001-6216-3962
}

\begin{abstract}
Within the framework of the signed Association Agreement with the EU, Ukraine has undertaken many obligations to harmonize its legislation with European norms, which gives our country the opportunity to import its products into the countries of the European Union almost without restrictions. One of these requirements is the prohibition of domestic manufacturers to use protected in Europe geographical indications of the origin of goods to indicate their products.

The problems related to preparation for registration and protection of geographical indications of food, wines, flavored wine products, alcoholic beverages as intellectual property are considered.

Nowadays Ukrainian producers are not too quick to change some names of domestic goods, which are borrowed by European geographical names and under the Association Agreement with the EU should not be used both in the foreign and domestic market.
\end{abstract}


Keywords: geographical name, geographical indication, name of origin, cognac, cognac alcohol, hackathon.

In order to protect their own manufacturers, many countries defend exclusive rights to use known geographical indications.

The term "geographical name/indication" itself is a name that identifies a product by a certain geographical location (not a geographical name), has a particular quality, reputation or other characteristics that are largely related to its geographical origin. Such products receive special brands, and this is a tool for protection and marketing. In particular, this indicates that the product comes from a certain territory, it is high-quality, authentic, unique, traditional. So, it immediately receives added value and brings profit to the owner.

The term "indication of origin" was mentioned back in 1883 in the Paris Convention "On the Protection of Industrial Property", in 1891 in the Madrid Agreement for the Repression of False or Deceptive Indications of Source of Goods and in 1958 - in the Geneva Act of the Lisbon Agreement on Appellations of Origin and Geographical Indications [1].

The legal basis of the protection of rights to indicate the origin of goods (geographical indications) was determined by the special Law of Ukraine "On the Protection of Rights to Indicate the Origin of Goods", adopted in 2001. In the new version of 2020, the Law is called "On the Legal Protection of Geographical Indications" and clearly defines the term "geographical indication".

According to the Law "geographical indication" is the name of a place identifying a product that comes from a certain geographical place and has a special quality, reputation or other characteristics, predetermined mainly by this geographical place of origin, and at least one of the stages of production of which (production (extraction) and/or processing, and/or preparation) is carried out in a certain geographical area".

This Law defines the principles of legal protection of geographical indications in Ukraine and regulates relations arising from their registration, use and protection. 
This is a framework document that is expected to adopt three sector laws that will regulate the use and protection of geographical names for agricultural products and food, as well as for wines and alcoholic beverages.

Within the framework of the signed Association Agreement with the EU, Ukraine has undertaken many obligations to harmonize its legislation with European norms, which gives our country the opportunity to import its products into the countries of the European Union almost without restrictions. One of these requirements is the prohibition of domestic manufacturers to use protected in Europe geographical indications of the origin of goods to indicate their products. Ukraine has registered a 10-year period of transition to new standards.

According to the information of the Ministry of Economic Development, Trade and Agriculture, in 2019, the first 10 Ukrainian products with protected names were determined to register the geographical name. They are: cheese is a protected name of origin "Hutsul sheep strap"; watermelon protected name of origin "Kherson watermelon"; cherry protected name of origin "Melitopol cherry"; honey protected geographical name "Carpathian honey"; wine protected name of origin "Shabsky", "Yal Pug", "Transcarpathia", "Belgorod-Dnestrovsky".

Currently, the "State Register of Ukraine of Place of Origin Names and Geographical Indications of Origin of Goods and Rights to Use Registered Qualified Indications of Origin of Goods" contains data on 45 protected geographical indications (except 3110 geographical indications of the EU, which are protected by Ukraine in accordance with the Association Agreement). But only 26 of them are directly Ukrainian. The name "Russian Vodka" and "Chacha" are protected in our country. And such traditionally "our" drinks and products as "Ukrainian vodka", "Medovukha", "Ukrainian honey" (although Ukraine occupies a leading position in the production of honey in the world), "Ukrainian fat" and others that have already become popular in Europe or can become them - are not placed in the register [2].

In Europe, more than 3.5 thousand geographical names have already been registered, and in Ukraine the system of its own geographical names is only in the 
process of formation, and today we have only one registered to the EU Regulation Ukrainian food product with a geographical name - "Hutsul sheep strap".

In the context of European requirements, Ukrainian manufacturers will have to review more than 3000 such names. Basically, they are alcohol and cheeses. For example, Ukrainian producers of feta cheese from 2023 will have to abandon this name, because it is a protected geographical name.

By 2026, it is necessary to abandon the use of protected geographical indication "cognac" for the product of domestic production.

In this regard, since December 2018, in the framework of the EU Project "Support to the Development of a Geographical Indications System in Ukraine" with the support of the Ministry of Agrarian Policy and Food of Ukraine, a discussion of a new name has started, which will replace "cognac". To develop potential names that Ukrainian entrepreneurs could use, 8 hackathons were held, to which representatives of various spheres related to the production, trade and marketing of these products were joined.

As a result of these events, as well as public online voting, during which Ukrainians chose a new name for their favorite drink, more than one and a half hundred names were proposed, 30 of which were taken to vote. More than $25 \%$ of respondents voted for the drink to be called "Ukrainian Brandy" or "Brandy of Ukraine"; 9.5\% chose the name "Amber"; 8.5\% - "Geister", "Chianok", "Dubovik", "Sonzedar". More than 16,000 responses and dozens of proposals were received during the voting. The variant of the name "Ukrainian Brandy" was chosen by the majority of votes, but the final name will be determined by commodity producers, and the profile ministry will approve it [3].

In order to achieve legal protection for its products regarding geographical indication, the manufacturer must prove that these products have unique properties (certain grape varieties, features of climatic conditions, production technologies, etc.).

The first geographical name by origin of "Cognac" was registered by the French Decree from 1909. To obtain the status of Geographical Territorial 
Designation IG Cognac must comply with the specifications that were approved by the French Decree "Cahier des charges" of 2011 [4].

Only Ugni Blanc grapes (98\% of the total grape harvest), as well as Folle Blanch and Colombard, are allowed for the production of cognac by law. This is due to the climatic and historical conditions.

To obtain real cognac, the wine must be produced from grapes growing on suitable soils (rocky and rich in limestone, as well as wooded with sandy soil, which form the "body" of the drink) and is abundant in sunlight. Another important factor that determines the uniqueness of French cognacs is the mountains of the Central Array, which do not pass cold winds from the north and trap moist air from the Atlantic. In addition, local methods of distillation, special compositions for aging alcohols, special types of wood for barrels, black fungus, covering the walls and roofs of cognac enterprises. If you delve into the history of the creation and formation of Cognac Houses of France, you can see that the creation of cognac is a series of unique traditions and family secrets that formed the today's brand of this drink [5, p. 97-98, 6, p. 30-51].

Unfortunately, Ukraine almost does not use this legal mechanism in the field of protecting the geographical name of products, despite the presence of historical traditions.

Most cognacs of Ukraine are non-competitive in the European and world markets not only by the name of the drink, but also organoleptic and physical and chemical indicators. Classification of domestic cognacs compared to French is imperfect and more complex. Ukraine uses the name "brandies of Ukraine" and their classification, borrowed from Soviet standards, which contradicts the principles of the Resolution of the Council of the ECC and the "Unified Regulation of the Organizations of the Common Market", where the guidelines for the protection of the names of wine products at the place of their origin are defined.

The use of incomprehensible, inconclusive interpretations and terms to determine the criteria of the quality and age of cognac alcohols and cognacs of Ukraine in DSTU 4700:2006 "Cognacs of Ukraine. Specifications" and KDU 
00011050 - 15.91 .10 - 5:2009 "Technical requirements for imported cognac spirits" can mislead both manufacturers and those who control the quality of cognacs. At the same time, these regulations do not take into account the control of the authenticity of cognac alcohols, the age of barrels and the degree of riveting depletion. The imperfection and bias of these documents is one of the reasons that inhibits the development of domestic viticulture and contributes to an increase in the volume of imports of cognac alcohols [7, p. 55-57].

In terms of ancient Ukrainian drinks, it can be noted that Ukrainians have never been excessively fond of vodka, although alcohol has been known since pagan times. Princes, cossacks and hetmans drank refined drinks. All ancient strong drinks were not strong at all: 5-10 vol. had medovukha and various hop tinctures. Thus, the traditional national raw material for the manufacture of strong and intoxicating beverages was honey. To this day, ancient recipes for the preparation of hopped honey drinks ("Kyiv honey", "Old World honey") have reached. A popular drink was the mussels - honey tincture.

Later, with the advent of vodka, liqueurs and tinctures were bypassed, the range of which was very diverse (varenukha, spotykach, starka, palenka, polynivka, mokrukha, tertukha, travnyak and many others) [6, p. 191-193]. Therefore, Ukrainian entrepreneurs should work on the creation and development of their own unique historical brands of drinks, and not use the world's popular names of foreign products for a long time.

\section{References:}

1. International practice of protection of rights to geographical indications of origin. URL: http://kojarskiy.com.ua/konsultacii_stati_14.html

2. Information of the "State Register of Ukraine of places of origin and geographical indications of origin of goods and rights to use registered qualified indications of origin of goods". URL: https://ukrpatent.org/uk/articles/kzpt-uk 
3. What Ukrainian goods will change their names. URL: https://ukronline.com/doings/31179-yak-ukrayinsk-tovari-zmnyat-svoyi-nazvi.html

4. Specifications for the registered designation of origin «Cognac» or «Eau-devie de Cognac» or «Eaude-vie des Charentes». - Published in BO AGRI on 15.01.2015. - I.N.A.O., 2015. - 20 p.

5. Bortnik O.I. (2008) All alcoholic drinks and cocktails of the world / Minsk: Harvest.- 240 p.

6. Cherevychna N. (2021) All about alcoholic beverages: a textbook / KhTEK KNTEU, 2021. 197 p.

7. Lukanin O.S. (2016) Criteria for determining the age of cognac alcohols. / Bulletin of Agricultural Science. - P. 51-60. 